\title{
Kamila Czaja
}

Wydział Humanistyczny, Uniwersytet Śląski w Katowicach

\section{„Świat przebrany, nieprzebrany”. Metafora tekstylna w poezji Stanisława Barańczaka}

Można wskazać co najmniej dwie ważne inspiracje do podjęcia tematu metafory tekstylnej w poezji Stanisława Barańczaka. Pierwsza to dostrzeżenie $\mathrm{w}$ wierszach poznańskiego twórcy licznych i pełniących zróżnicowane funkcje odwołań do ubioru. Drugą, niezależną, ale potwierdzającą te intuicje, stanowi publikacja Joanny Grądziel-Wójcik: Przymiarki do istnienia. Wątki i tematy poezji kobiet XX $i$ XXI wieku, głównie rozdział Między metafizyka a zaangażowaniem. Metafora tekstylna w poezji Ewy Lipskiej. Poznańska badaczka już we wstępie do książki zauważa:

Metafora sukni rozumianej jako drugie „ja” umożliwia na przykład prześledzenie wątków tożsamościowych, łączących meandrycznie problematykę metafizyczną z cielesną oraz ujawniających zaangażowanie tej poezji w doczesność i wieczność - „tutejszą” rzeczywistość i „tamtą” niepewną przyszłość. [Grądziel-Wójcik 2016: 8]

Choć w przypadku Barańczaka kluczowa nie jest „metafora sukni”, to lektura jego wierszy uświadamia, że „przymiarki do ist- 
nienia” nie zostały zarezerwowane wyłącznie dla poezji kobiet, że nie tylko w niej

motywy tekstylne [...] okazują się [...] obrazowymi i poważnymi formami (przymiarkami) kreacji istnienia, które pociągają za sobą pytania o transcendentną podszewkę rzeczywistości, wiodą w kierunku intelektualizacji i (auto)refleksyjności wypowiedzi oraz służą mówieniu o kondycji nie tylko kobiecego podmiotu. [Grądziel-Wójcik 2016: 8-9]

W utworach Barańczaka związane ze strojem wątki kierują uwagę w stronę zarówno teraźniejszego konkretu, jak i uniwersalnych kwestii egzystencjalnych. Dochodzi tu do poetyckiego wykorzystania właściwości ubioru, o których pisze Grażyna Bokszańska [2004: 56]:

Ubiór [...] posiada zdolność przenoszenia uwagi [...] w świat idei, wartości, stanów emocjonalnych, przeżyć i poglądów. Staje się znakiem i na tej zasadzie odsyła do przedmiotów i stanów innych niż on sam.

\section{Wyprana skóra świata}

Barańczak czasem prezentuje abstrakcje za pomocą tekstylnej metafory, czasem traktuje strój jako znak czasów czy realiów. A świat tych wierszy sam chwilami zdaje się „uszyty” - jak w wierszu Zbudzony w jeszcze głębszy sen: „[...] Tak się więc tka płótno // dnia, przepalając jedną nitkę drugą" [wz: 34]. Za kluczowy dla tekstylno-tekstowej wizji poety uznać można fragment utworu 15.2.80: Śnieg VI, zbudowany na przejściu od przenośnego sensu frazeologizmu „wilk w owczej skórze” do dosłownego okrycia: „kożucha”. Następnie rzeczywistość odsłania swoją naturę w metaforze rodem $\mathrm{z}$... pralni:

Ten biało farbowany lis, ten świat, ten wilk w owczej skórze śniegu, niewartej wyprawy w głąb, do żywego mięsa ziemi - kilku chwil 
wystarczy przecież, aby ten kożuch, wyprany

i tak chemicznie ze Wszystkiego, Niczym

stał się, kiedy wiatr ciepły dobierze mu się do skóry,

kiedy z niej mało zieleń nie wyskoczy; [...].

[wZ: 256]

Wielkie litery („Wszystkiego”, „Niczym”) oraz świadomość „podskórnych” sensów poezji Barańczaka każą myśleć o tej zmianie zdecydowanie szerzej niż tylko w kontekście pór roku. Kolejne wersy: „[...] niszczy / wierzchnie okrycia, zrzuca wciąż skórę ten wilk, / ten lis, ten świat przebrany, nieprzebrany [...]” [wz: 256] przynoszą zwięzłą, zakorzenioną w ciągu zwierzęcych i tekstylnych równocześnie metafor charakterystykę rzeczywistości. Świat jest nie tylko „przebrany” (za coś, a więc udający, zwodzący) i „nieprzebrany” (niepoznawalny w pełni) - lecz także „nieprzebrany”, bo, jak wynika z finalnych wersów, podszyty nagością (co w kontekście szycia dość paradoksalne), która sama stanowi tajemnicę: „drapieżnik, zawsze błyśnie nagim, tajemniczym / pstrokatym ciałem fiołków, rdzy, błota i wilg” [wz: 256]. Jak zauważa Joanna Dembińska-Pawelec [1999: 50]: „Świat odradzający się ukazany jest w tych wierszach poprzez odwołanie do odwiecznego symbolu wiosny - zwycięstwa życia nad śmiercią, wolności nad niewolą".

\section{Co na siebie włożyć?}

Czytana pod kątem położenia człowieka w „przebranym” świecie poezja Barańczaka przynosi całą listę tekstylnych sposobów przetrwania. W Wiekach średnich czas to „zbyt obszerny puklerz”; „Fałdy czasu” są „zbyt luźne i sute”, a ludzie epoki okazują się „Nadzy w zbroi, w czasie” [wz: 20]. Na niejednoznaczność takiej sytuacji zwraca uwagę Piotr Bogalecki [2016: 45], który pokazuje, że cytowane tekstylne metafory nie muszą być znakiem kruchości ówczesnego istnienia, lecz mogą stanowić wyraz oczywistego dla ówczesnych ludzi porządku, w którym „puklerz” nie tylko krępuje atak, lecz także przed nim broni; „fałdy czasu” przypominają Sanatorium Pod Klepsydrą Brunona Schulza i sugerują, że śmierć nie ma 
tu władzy, z kolei nagość podwójna podpowiada, że „nieistotna jest różnica pomiędzy nagością fizyczną i «egzystencjalną»”.

Zwraca też uwagę bardziej współczesna, typowo konfekcyjna metafora Barańczaka w wierszu Z rzadkiego błota, z gliny: ,powraca ze spaceru mieszkaniec, ciało w jesionce, /wilgotna glina, której co chwila nowy rozkaz // wydaje śmierć [...]" [wz: 222]. Ten tekstylny fragment zajmował interpretatorów poezji Barańczaka. Krzysztof Biedrzycki [2006] uznanie człowieka za „ciało w jesionce” komentuje: „Niekiedy wydaje się, że jest ciało i tylko ciało, i nic nie ma poza ciałem”. Dembińska-Pawelec [1999: 44] przywołuje tę frazę $\mathrm{z}$ wiersza w kontekście typowego dla tomu Tryptyk $z$ betonu zmęczenia $i$ śniegu „traktowania życia jako śmierci”. Z kolei Dariusz Pawelec [1992: 79] traktuje słowa „ciało w jesionce" jako jeden z przykładów na to, że

Barańczak podważa antropocentryczność portretowanego świata. Człowiek został w nim bowiem sprowadzony do swych funkcji fizjologicznych. Nie jest ani jego ośrodkiem, ani celem. $\mathrm{Z}$ podmiotu stał się przedmiotem $[\ldots]$.

Metafora związana z ubraniem może więc ukazać moc śmierci ${ }^{1}$; sytuacja wydaje się jednak bardziej skomplikowana, bo strój to również broń przeciw związanej z tą mocą rozpaczy. Kluczową rolę odgrywa tu szalik. Grądziel-Wójcik [2016: 80] w kontekście twórczości Marii Pawlikowskiej-Jasnorzewskiej pisze:

Motyw ten [suknia - K.C.] może także rozrastać się do metafory świata utkanego dla człowieka (zaprojektowanego dla niego, skrojonego na jego miarę), przywołując postać Stwórcy jako tkacza czy krawca i problematyzując tym samym niepewny status Absolutu. w poezji Marii Pawlikowskiej-Jasnorzewskiej: „Suknia jest tu rozumiana jako znak egzystencjalnej kondycji człowieka - metonimia kruchości jego ciała i nietrwałości teraźniejszości, ale też jej materialnego zakotwiczenia i intensywnej, naznaczonej (choć niekoniecznie) kobiecością obecności w wymiarze osobistym, tożsamościowym". 
Natomiast w rozdziale o poezji Ewy Lipskiej zauważa: „Poetycka wersja wydzierganego czy skrojonego świata rodzi pytanie o jego projektanta, każąc zastanowić się nad konsekwencjami jego działań oraz odpowiedzialnością za los człowieka” [Grądziel-Wójcik 2016: 93 ].

W wierszu Barańczaka 1.11.79: Elegia pierwsza, przedzimowa pojawia się podobna wizja świata: „[...] a mróz trzyma // długo, choć trzyma nas krótko za twarz schowaną w szaliku. / Nas nie zaskoczy zima. Nas zimy przygotowały / na najcięższe krawiectwo [...]” [wz: 227]. Pamiętać należy, że „[o]braz zimy w elegii Barańczaka został spojony $\mathrm{z}$ obrazem śmierci w jedno widzenie poetyckie" [Pawelec 1992: 104]. Człowiek jest wszak przygotowany: wie, że twarz musi chować w szaliku. Jeśli jednak wiara w skuteczność tej recepty wydaje się nadmiernym optymizmem, to słusznie, bo już utwór 20.3.80: Elegia czwarta, przedwiosenna pokazuje, że to rozwiązanie prowizoryczne, nastawione na przetrwanie, a nie prawdziwe życie: „i zacznę żyć naprawdę, na całego, na oścież / targnę koszulę serca - a tymczasem roztropnie / czekać - trzymać się ciepło - o szaliku pamiętać - // Ale nie ma innego życia. [...]" [wz: 259]. Jednak i taki sposób nie zawsze działa, o czym przypomina wiersz 2.1.80: Eroica. Radę, by „Schwycić swój los za gardło”, opatrzono w nim sceptycznym komentarzem: „nie jest obudowane grubymi mięśniami / ani okutane cienkim szalikiem, z niego / nie dobywa się ani krwawy ryk, ani kwaśny / oddech, jego po prostu nie ma, // tego gardła [...]” [WZ: 247].

Istnieją jednak jeszcze inne recepty, „co na siebie włożyć” w obronie przed światem. Trzeba zachować umiar, nie przywiązywać się do rzeczy i miejsc - wszak „jeżeli odzież, to tyle, ile można unieść w walizce" [Jeżeli porcelana, to wyłącznie taka, wz: 218], pozbyć się złudzeń: „Zdrapać uśmiech, zwlec skórę, odjąć ruchy, nawet cień odrąbać od siebie niezamierzonego, zamotanego w fałszywe powijaki” [Drugi, wz: 38] lub przeciwnie - karmić się nadzieją, wkładając „[...] do kieszonek serc / paszport z trwałą ważnością, ale w czasie przyszłym” [30.1.80: Śnieg IV, wz: 248]. Można też skorzystać z koniecznego wyposażenia otrzymanego już na wstępie jako wymóg czasów - ta wizja, zaprezentowana 
w Kolędzie z wykorzystaniem metafory językowej, ściślej: rozerwania frazeologizmów [zob. Pawelec 1992: 44-51], zakłada m.in. urodzenie się „w stalowym czepku” [wz: 68]. Metody to jednak albo zawodne, albo naiwne, albo agresywne i prowadzące do zgorzknienia. Trudno się więc dziwić, że - kolejna metafora tekstylna ludzie charakteryzowani są jako ci, „którzy zawsze wniosą w świat na podeszwach / brud niepokoju”" [Cape Cod, wz: 359]. Skrajnie odmienne zachowania związane z ubiorem stają się też sposobem uchwycenia paradoksalnej natury „prostego człowieka”, który bywa irytująco niekonsekwentny - nie można jednoznacznie stwierdzić, czy jest „kimś, kto ściągnie ostatnią koszulę z grzbietu, jeżeli / przyjaciel w biedzie? kto ściąga przezornie buty (świadomy, / że i tak ktoś to zrobi) z nóg rannego, który zań walczył?” [„Prosty człowiek mógłby, do licha, zdecydować się wreszcie, kim jest”, wz: 440].

Kiedy człowiek żyje w tak „skrojonym” świecie, zostaje $\mathrm{mu}$ - poza szalikiem - tylko trzymanie, nomen omen, fasonu. Jak w wierszu 1.1.80: Elegia trzecia, noworoczna, którego bohater „myśli cierpko i błogo, / że jeszcze ten dzień wytrwa”: „[...] Siwe włosy / liczy i zanim włoży / marynarkę i krawat, / myśli cierpko i błogo, / że jeszcze ten dzień wytrwa" [wz: 245].

Wyrazisty przykład stanowi tu wiersz Od Knasta, w którym do głosu dochodzą wyrzuty sumienia wobec dziecięcej (i dziecinnej) pogardy wymierzonej w rytuał i styl, m.in. styl ubierania, ludzi, którzy w każdą niedziele idą po ciastka: „[...] nawet wtedy nie wolni, nie luźni, / przeciwnie, wprasowani w biel koszuli, w stary / szczękościsk srebrzystego lisa wokół szyi / żony [...]” [wz: 466].

Po latach dopiero pojawia się refleksja, że forma nie jest tu tylko formą - że stanowi obronę przed światem:

2 Ślad buta w poezji Barańczaka jest potraktowany także ironicznie, ale wobec przemijania to jeden z nielicznych dostępnych śladów zaistnienia człowieka - nawet jeśli niewłaściwie interpretowany przez obserwatorów: „[...] geometria rowków podeszwy / tenisówki Nike - jej ślady obserwator z odległych galaktyk / bierze pewnie za produkt masowych a tajnych praktyk / religijnych, wyciskaną jak pieczęć na każdej poziomej powierzchni / aluzję do odkrywkowych kopalń, tej późnej wersji katakumb)" [Czas tak cierpliwie znosi, wZ: 469]. Obuwie traktuję w niniejszym artykule, podobnie jak Grądziel-Wójcik w Przymiarkach do istnienia i Maguelonne Toussaint-Samat w Historii stroju, jako część ubioru. 
[...] Dziś mój wstyd, potworny:

przypuszczać, choćby dzieckiem, że ta biała laska, to pudełko co tydzień, było kwestią formy;

nie dostrzec, że jeżeli jest coś, co pomaga trzymać się życia, iść przez ujadanie sfory dni - jeszcze żałośniejsza jest moja pogarda...

[wz: 466]

Adam Poprawa koncentruje się na rytuale i ciastkach, nie na elementach ubioru noszonego podczas tych spacerów; również w taki sposób postrzega dbałość o zachowanie form w tym wierszu:

Niedzielne wyprawy do jego [Knasta - K.C.] sklepu stawały się rodzajem obrzędu, nie znajdującego jednak uznania w oczach dziewięcioletniego obserwatora. Dla niego było to tylko [...] snobizmem, tylko kwestią formy. Tymczasem okazało się aż kwestią formy. Innymi słowy: trzymanie się nawet błahego obyczaju spełniać może rolę wręcz sensotwórczą. [...] Bardzo ostro postrzega ich dziecko. We wspomnieniu ten sąd zostaje odrzucony, lecz w dojrzałej łagodności kryje się jeszcze jedna, już naprawdę bardzo trudna kwestia: a jeśli nie tylko ciastka są dosyć zabawną formą ocalania, jeśli wszystkie formy pomagające trzymać się życia skazane są na nieuniknioną niepełność i niewystarczalność?3 [Poprawa 2003: 78-79]

Metafora tekstylna w poezji Barańczaka nie zawsze jednak dotyczy - nawet jeśli opowiedzianego za pomocą konkretu - ogólnego poziomu mechanizmów życia i śmierci oraz wątpliwych efektów samoobrony człowieka wobec nich. Niejednokrotnie sięgał autor po taki środek także w wierszach politycznych.

Podobnie pisze Danuta Opacka-Walasek [2016: 36]: „Mieszczański teatr, wcielanie się w kostiumy, pozorowanie rutynowo granymi rolami lepszych swoich cnót niż są w rzeczywistości, jednocześnie odstręczał Barańczaka i powodowal właśnie przez ów odruch pogardy - wyrzuty sumienia, a nawet identyfikację. Mam na uwadze jego wiersz Drobnomieszczańskie cnoty oraz, w jeszcze większym stopniu, Od Knasta, z jakże dobitną puentą, która nicuje podszewkę tego teatru: trudny do udźwignięcia metafizyczny lęk i próbę zagadania go [...]”. 


\section{Rozbieranie systemu}

Grądziel-Wójcik [2016: 85] pisze o tekstach Lipskiej „wykorzystujących motyw sukienny i semiotykę strojów do opisu procesów historycznych i społecznych”. I znów - nie suknia będzie w wierszach Barańczaka tekstylnym obiektem głównym, ale inne materiały i ubrania, które pełnią w jego twórczości podobną funkcję4. Pojawia się wiele fraz tekstylnych, czasem będących częścią charakterystyki żyjących w epoce ludzi, a czasem, co literaturoznawczo najciekawsze, wpisanych w koncept metaforyczny budujący cały utwór lub jego istotny fragment.

Najprostsze przykłady to rejestrowanie ubrania jako elementu wyglądu obywateli. Jest więc spojrzenie w „oczy potrąconego przypadkowo / przechodnia z podniesionym kołnierzem [...]” [Spójrzmy prawdzie w oczy, wz: 95], dziewczyna w tramwaju „w tandetnym płaszczu, z trzema pierścionkami / na palcach, z resztką snu w zapuchniętych oczach" [N.N. próbuje przypomnieć sobie stowa modlitwy, wz: 125]; odnotowano też to, że umierająca w kolejce kobieta upadała, „czepiając się cudzych toreb i jesionek [...]" [Każdy może stać, wz: 270]. I jeszcze - w ramach tego, że poeta „kontestuje nie tylko zastaną strukturę polityczną, ale i społeczeństwo, z którym chce tę strukturę zmienić” [Poprawa 2014: 17] - uwzględniono niechlujne ubranie jako jedną z irytujących ludzkich wad: „Gdyby nie ludzie, gdyby nie istnieli / tak natrętnie, ze swoim łupieżem, paranoją, / wystrzępionymi spodniami, antysemityzmem"s [ Gdyby nie ludzie, wz: 229].

4 Nawet jeśli nie ma tu wielu tak wprost pomyślanych zestawień jak w poezji Lipskiej, np. w Zwierzeniach emigranta, w których ojczyźnie kupili „kapelusz / z pawimi piórami. Czerwoną sukienkę” [OE: 425], czy w utworze Stanisława Stabry Ten wiersz ma na imię Polska, w którym tytułowy wiersz „chodzi w wytartych bucikach / i zmęczonej sukience” oraz „drepce na piechotę / w źle skrojonym płaszczu" [OE: 292].

5 Dochodzi do tego jeszcze krytyka „[...] wycierających zamaszyście / buty straszne dziś błoto [...]" [wz: 229]. Warto dostrzec podobny, choć tu autokrytyczny obraz w Rewolucjoniście przy kiosku z piwem Krzysztofa Karaska: „Co ja tu robię, wśród tych ludzi, / wśród tego zgiełku, w kapeluszu mysioszarym, / $\mathrm{z}$ wyleniała czaszką / / Z wydaniem ostatniego dziennika, / z parasolem, w przydeptanych butach, / z wystrzępionymi makietami spodni / [...] / pozór odziany w garnitur, wysłużona marynarka" [OE: 122, 123]. 
Tego typu frazy nie tylko wskazują na „bylejakość” peerelowskich realiów, ale także są po prostu sposobem ukonkretnienia bohaterów ${ }^{6}$. Ciekawiej robi się, gdy element stroju jaskrawo kontrastuje z nieczystymi intencjami noszącego go człowieka - i to niezależnie od tego, czy chodzi o PRL, czy o Stany Zjednoczone. Doskonale ukazuje to w wierszu N.N. rzuca $w$ przestrzeń naiwne pytania jedno $\mathrm{z}$ tytułowych pytań skierowane do prezentera „Z ekranu”, które brzmi: „[...] Czy nie dusi cię / gustowny krawat barwy wiosennego nieba?” [wz: 144], a telewizyjny kaznodzieja w nadziei na czeki „[...] grzmi z piętrowych estrad, w jaskrawoniebieskim / smokingu z poliestru [...]" [Ustawienie głosu, wz: 365 ].

Sytuacja robi się najciekawsza, gdy ubrania wkraczają na teren większej ustrojowej metafory. Czasem takie frazy sytuują się na pograniczu znaczeń uniwersalnych i politycznych, jak w zbudowanej paralelnie parze $\mathrm{z}$ wiersza Bo tylko ten świat bólu: kula ziemska „trzeszcząca w granicach / grubymi nićmi szytych”, a ciało „trzeszczące pod pałką / w kostnych szwach czaszki” [wz: 75]. Zniewolenie daje o sobie znać także poprzez metafory dotyczące „stroju” zwierzęcego - „kaganek kagańca” [wZ: 81] z wiersza U końca wojny dwudziestoletniej - oraz w całym szeregu elementów militarnej „mody”: model na propagandowym plakacie ma czoło, które „[...] mieści się swobodnie w znormalizowanym / hełmie” [Plakat, wz: 89]. Antywojenne rozważania w Ja wiem, że to niestuszne idą wbrew wpajanej przez polityczny system świadomości, że „niesłuszny był kształt hełmu, niewłaściwy / model karabinu, nie ten okop [...]" [wz: 197]; rodzi się niezgoda na obojętność wobec cudzego cierpienia, nawet jeśli „[...] myślenie o tym nie jest mi na rękę. / ani na tę w rękawie mundurowym, ani / na tę związaną drutem [...]" [To mnie nie dotyczy, wz: 199].

Istnienie ciągłego zagrożenia konformistycznego trybu funkcjonowania w systemie ${ }^{7}$ wyraża także zmiana stroju z mieszczań-

6 W takiej roli pojawią się również w wierszach emigracyjnych: „otrzepywanie nogawek” i „brunetka w futrze” w Mszy za Polskę w St. Paul's Church, grudzień 1984 [wZ: 293], „kurtki z mnogością fachowym kieszonek” w Obserwatorach ptaków [wz: 368], ,watowane kurtki” w Implozji [wz: 423] czy bosman ,widziany tylko w knajpach w swej koszulce w paski” [Płynąc na Sutton Island, wZ: 488].

7 „Trzy strofy wiersza zdają się odpowiadać trzem rodzajom podporządkowań, którymi są: konsumpcja dóbr materialnych $[\ldots]$ konformizm w relacjach spo- 
skiego na żołnierski: „[...] ci wszyscy / poubierani dzisiaj / w skarpetki, w szelki, wyfasują jutro / pas i onuce; i pójdą, nakryci / paradoksalnym parasolem ognia" [Ci, którzy jedzą grzanki, będą jeść suchary, wz: 83].

Na metaforze tekstylnej - ale przewrotnie, bo na takiej wcześniej już wpisanej we frazeologizm - buduje Barańczak tekst Przysłowiowa bawetna, już od tytułu ironizując: wszak słowo „przysłowiowa” to w takim kontekście błąd ${ }^{8}$. Poeta pokazuje zakłamanie systemu, który odwraca zwyczajowy porządek i cel komunikacji:

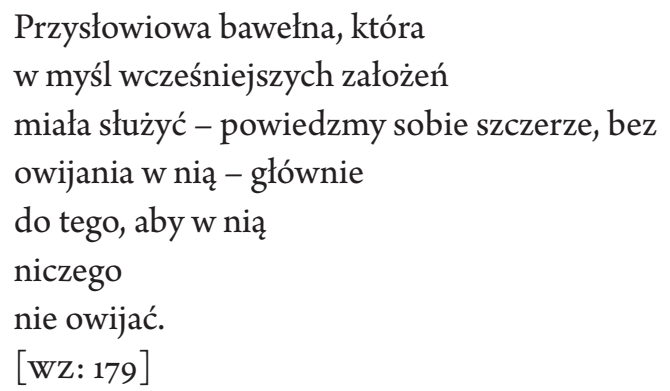

Tak było z „przysłowiową bawełną” dawniej, natomiast „w chwili obecnej / należy do rzędu tekstyliów szczególnie modnych i poszukiwanych" [wz: 179]. Wiersz obnaża jednak te zafałszowania, pokazując, że kłamstwa i tak łatwo dostrzec, a propaganda działa przeciwskutecznie - co doskonale ukazuje metafora językowa (kontaminacyjna), zgodnie z którą bawełna „kurczy się w praniu / mózgów [...]" [wz: 179]. W efekcie - wyraża to udo-

łecznych $[\ldots]$ i zbiorowa religijność [...]. Dwa pierwsze wydają się jakby odnowionym motywem Różewiczowskiej «małej stabilizacji» lat 60., spotęgowanym nowofalową ostrością widzenia" [Kandziora 2007: 61-62].

8 Włodzimierz Bolecki [1985: 162] zauważa: „[... ] podmiot wiersza od razu sygnalizuje swój dystans wobec mowy propagandowej. Wyraz «przysłowiowa» pełni funkcję deiktyczną - wskazuje, że językowy stereotyp to martwy wytwór masowej komunikacji. Stereotyp ten nie jest już dalej przekształcany, podmiot nie ujawnia ukrytych w takim zwrocie dodatkowych znaczeń, lecz pokazuje mowę własną jako obronę przed banałem, schematem i propagandowym stereotypem. Właśnie ukazywanie odrębności mowy własnej podmiotu (ironii, zabawy, groteski, kalamburu) służy równoczesnemu odrzuceniu językowych wyrobów masowej komunikacji (propagandy, ideologii, doktryny)". 
słownienie przysłowia „kłamstwo ma krótkie nogi” i zwrot „ukrywać pod płaszczykiem" - kłamstwo, choć owinięte w bawełnę, zdradza swoje prawdziwe oblicze: „[...] choć kłamstwo ma krótkie nogi, to i tak / wystają / spod przysłowiowej bawełny na dobry kilometr, / kiedy kłamstwo próbuje się skromnie ukryć pod / różowym płaszczykiem / bawełnianego języka" [wz: 179].

Ci, którzy ten język wykorzystują, oraz ci, którzy mu się ofiarnie podporządkowują, też mogą zostać określeni poprzez odwołania do elementów odzieży: „o, karki pogrubiałe; kolczasta obroża / z jedliny pęknie na was; plecy w marynarkach, / nie was chłostać rózgami róż $[\ldots]$ ] [Złożyli wieńce i wiązanki kwiatów, WZ: 91]; „ci z twardą ręką, zdatną do walenia w pulpit / mównicy i klepania po ramieniu / zgiętych w ukłonie ludzi, przyszpilonych przed chwilą / orderem do czarnego garnituru" [Ci mężczyźni tak potężni, wz: 204].

Stroje stanowią także tło rozliczeń N.N. w wierszu N.N. przyznaje się do wszystkiego - od chowania rąk do kieszeni: ,to on кто JEST PRZECIW NIE WIDZĘ wkłada szybko obie ręce do kieszeni, aby przewodniczący zebrania nie miał wątpliwości” [wz: 123], po ratowanie się ukrytą za pazuchą piersiówką, podczas gdy druga ręka dopasowuje się do wymogów stadionowej zbiorowości: „[...] na baczność, z jedną ręką ZA TWOIM PRZEWODEM na szwie spodni, a palce drugiej, błąkającej się w okolicy serca ZŁĄCZYM SIĘ $\mathrm{Z}$ manewrują już przy ciepłej zakrętce butelki zwanej piersiówką" [wZ: 124]. W utworze $Z$ nami nie zginiesz zagarniający jednostkę tłum stoi odświętny (aczkolwiek nieco już nieświeży) „w przepoconym blasku / białych koszul” [wz: 201]; najdobitniej „tekstylność" państwowych uroczystości prezentuje jednak inny wiersz:

Na tych ulicach, które kilkanaście razy do roku przybierają odświętną szatę (a kolor jej jest czerwony, bo na niej), na tle tych wielkich portretów

9 Analogiczny obraz wstydu, jakim jest otrzymanie nagrody od portretowanego systemu, choć bez wprost przywołanego elementu garderoby i z „wbiciem” w miejsce „przyszpilenia”, przynosi Piosenka znad sufitu: „i będziesz już na wieki / na pamięć i na śmierć / przyzwoitym człowiekiem / z orderem wbitym w pierś" [wZ: 147]. 
malowanych techniką wcierkową (a kolor ich jest brunatny, bo), obok tych kolosalnych liter ze [styropianu, niesionych

w każdym pochodzie (a kolor ich jest z niewiadomych [przyczyn

śnieżnobiały).

[W zasadzie niemożliwe, wz: 163$]$

Z „odświętną szatą” ulicy - czerwonej w nawiązaniu do pieśni rewolucyjnej Czerwony sztandar Bolesława Czerwińskiego [zob. Biedrzycki 1995: 41; Pawelec 1995: 78] - skontrastowano jednostkę wyjątkową, bo szarą: „w zasadzie nie ma prawa pojawić się ktoś taki, / o mózgu tak wyzywająco szarym””[ [wZ: 163]. Równocześnie z przeciwstawieniem szarego człowieka „wystrojonym” ulicom dochodzi do przeciwstawienia go innym obywatelom, którym taka „anomalia” nie jest potrzebna:

\section{[...] nie potrzebuje go młody}

człowiek w płaszczu ze sztucznej skóry, odkładający

wątpliwości na później, a nadzieję na

książeczkę oszczędnościową, nie na jakąkolwiek

z książek.

[wz: 163]

Jak zauważa Pawelec [1992: 142]: „«Szarość» w obrębie omawianej twórczości nie posiada jednak jednoznacznie sprecyzowanego nacechowania” - może być znakiem nijakości, ale w innych tekstach przynosi pozytywne konotacje jak właśnie w cytowanym utworze: „Z podobnym przeciwstawieniem mamy do czynienia właśnie w przypadku wiersza $W$ zasadzie niemożliwe. Pojawienie się bohatera lirycznego jest w nim poprzedzone [...] hiperbolicznym opisem odświętnej ulicy. Dominują w tym opisie kolory: przemocy (brunatny) i propagandy (czerwony, biały). W opozycji do nich «szarość» bohatera w sposób paradoksalny wyrywa go z kręgu przeciętności i pospolitości” [Pawelec 1992: 143]. Ciekawie brzmi w tym kontekście myśl z eseju Barańczaka [1990: 191] E.E., przybysz z innego świata: „Kolorem Europy Wschodniej jest, jak wiadomo, szarość (ożywiana tylko przebłyskami czerwieni z okazji świąt państwowych). Ameryka nie ma określonego koloru: jest jaskrawo wielobarwna, kolorystycznie pluralistyczna, już na pierwszy rzut oka wieloznaczna i śmiała”. Z jednej strony przeciwstawia poeta ponury obraz bloku wschodniego barwnej Ameryce, z drugiej - szarość i tu wydaje się mniejszym złem niż czerwień państwowego święta. 
Ten młody człowiek stoi po stronie tego, co materialne, a jego płaszcz stanowi wyrazisty znak takiej przynależności [zob. Pawelec 1992: 141].

Biedrzycki [1995: 41], podkreślając nieprzypadkowość kolorów w wierszu $W$ zasadzie niemożliwe, po rozszyfrowaniu oczywistej komunistycznej czerwieni zauważa:

Ale zaskakująco pojawia się kolor brunatny. Tutaj fraza pieśni urywa się w połowie, jakby śpiewający nagle zorientował się, że kończąc ją zagalopowałby się w nazbyt ostentacyjnych skojarzeniach (oczywiście kolor brunatny oznacza tutaj faszyzm w ten sposób gra kolorystyczna demaskuje podobieństwo obu systemów totalitarnych). Podobne zderzenie barw, w sposób jeszcze bardziej jednoznaczny, występuje w wierszu N.N. rozmyśla o dalszych perspektywach [...].

Co ważne w kontekście niniejszych rozważań, to fakt, że „podobne zderzenie barw” ukazano za pomocą metafory tekstylnej: „Jeszcze nie jest tak źle; jeszcze można wybierać / każdego ranka / pomiędzy brunatną koszulą a czerwonym krawatem, / jeszcze nie jest tak źle, / można się jeszcze ubrać, w co kto lubi” [N.N. rozmyśla o dalszych perspektywach, wz: 148].

Taki „garderobiany”, wyraźnie wątpliwy wybór znajdzie w kolejnej strofie rozwinięcie: „między drutami lagru a drutami łagru” [wz: 148]. Wybór między „brunatną koszulą” a „czerwonym krawatem" to jedna z najdosadniejszych tekstylnych metafor Barańczaka, ujmująca w elementach ubioru dwa totalitarne systemy, w których pułapce znajduje się jednostka wybierająca między jednym a drugim złem - i żadne nie wydaje się tym mniejszym $^{11}$. cie w poezji Ryszarda Krynickiego. W jego wierszu o metaforycznym tytule Faszyści znowu zmieniają koszule pojawiają się także cząstkowe metafory tekstylne: „Czarne koszule zmieniają na białe godziny”, „Na białych koszulach mniej widoczne są ślady mózgu, / na czarnych koszulach mniej widoczne są ślady krwi” [OE: 75-76]. 


\section{Z żurnala spiskowca}

A co, jeżeli ktoś nie godzi się ani na „brunatną koszulę”, ani na „czerwony krawat”? Wtedy zostaje funkcjonowanie w opozycji do systemu, rola spiskowca, którą w kontekście Dziennika zimowego opisuje Pawelec [1998: 67; por. Dembińska-Pawelec 1999: 38]:

W Dzienniku porannym nakreślony został program jednostkowego heroizmu wyrażony w duchu prometejskiej samowystarczalności człowieka - bohatera. Konsekwencje zrealizowania tego programu oglądamy na kartach Ja wiem, że to niestuszne i Tryptyku: zapis poetycki uzyskał w tych tomach etyczną sankcję. Poeta przyjął rolę „spiskowca” i „więźnia”.

Poetyckie opowieści o losach spiskowca zawierają wiele szczegółów związanych z ubraniem. To swoisty żurnal (słowo kojarzące się nie tylko z czasopismem modowym, ale także z dziennikiem) strojów noszonych w ramach ryzykownej dysydenckiej działalności. Tom Ja wiem, że to niestuszne przynosi przeciwstawienie „prywatnego” i „oficjalnego”, w wierszu Te słowa wyrażone m.in. antynomicznością stroju [por. Pawelec 1992: 81-82]: „Te słowa z mównic i te w rozmównicach, / te grubą nicią głosu zszywane / w granatowy worek garnituru i / tamte, rozbierane do naga z drelichu / przed osobistą zniewagą rewizji”" [wZ: 170].

W kontekście spodziewanego zatrzymania pojawia się konieczność przypomnienia żonie, „aby nam spakowała zawiniątko z ciepłą, / jak najcieplejszą bielizną [...]” [Gdzie drwa rąbia (II), wz: 184], natomiast zatrzymujących cechują zupełnie inne garderobiane dodatki: „Błyśnie złoto ich zegarków” [Trzej Królowie, wz: 188]. Przykłady „mody” spiskowej przynosi też Dziennik zimowy. W wierszu 8.2.80: I nikt mnie nie uprzedzit wolność i niewola okazują się zaskakująco sobie bliskie [por. Bie-

Występuje tu na dodatek obnażająca fałsz mowy oficjalnej metafora krawiecka: „Ich [«słów z mównic» - K.C.] prawdomówność podważona jest np. omówieniem: «(słowa) grubą nicią głosu zszywane», bazującym na frazeologizmie szyć coś grubymi nićmi, który wyraża poznawczą nieufność” [Pawelec 1992: 82]. 
drzycki 1995: 236]. Obrazuje to sytuacja przeszukania, w której zaakcentowano odzieżowe elementy:

I nikt mnie nie uprzedzil, że wolność może polegać także na tym: że siedzę w komisariacie $\mathrm{z}$ brulionem własnych wierszy ukrytym (co za przezorność) w nogawce zimowej bielizny $[\ldots]$

I nikt mnie nie uprzedził, że niewola może polegać także na tym: że siedzę $\mathrm{w}$ komisariacie $\mathrm{z}$ brulionem własnych wierszy ukrytym (co za groteska) w nogawce zimowej bielizny. [wZ: 252]

Natomiast w kolejnym wierszu z tomu Tryptyk z betonu, zmęczenia i śniegu, czyli utworze 9/10.2.80: Czterdzieści osiem, skontrastowano kilku zatrzymanych poprzez zestawienie ich ubioru:

W zakratowanym zaduchu, na nieugiętych deskach próbuję zasnąć, ogrzewany z lewej przez robociarza w kitlu (kradzież narzędzi), z prawej przez waluciarza w kożuchu (zakłócenie spokoju w stanie wskazującym). Co ja mam z nimi wspólnego poza tą wspólną celą. [wZ: 254]

Równocześnie, na przekór tym antynomiom, więzienne doświadczenie rodzi poczucie wspólnoty:

Wiele ludzi dzieli w życiu społecznym, łączy ich wspólnota odczuwania. Paradoksalnie więc więzienie okazuje się szkołą solidarności i porozumienia między ludźmi, którzy gdzie indziej nie potrafiliby znaleźć wspólnego języka. [Biedrzycki 1995: 106]

W późniejszych tomach tekstylne motywy jako element oporu wobec systemu jeszcze przez jakiś czas powracają. W Atlan- 
tydzie, w Przywracaniu porządku, dysydenta cechuje „czarna opaska na rękawie” [wz: 281], a decydentów scharakteryzowano jako „sztywno się trzymających, z twarzyczką nadętego niemowlęcia / nad dorosłym krawatem [...]" [wz: 283]. Ciekawa metafora tekstylna pojawia się też w utworze Cóż dzisiaj, w którym użyte jako motto wezwanie Peipera: „Była niegdyś od morza do morza, / dziś być musi od dłoni do dłoni” [wz: 291] przybiera zaktualizowaną formę, m.in. w wersach: „Dziś być musi od ciała do koszuli, na grubość / pliku świeżych ulotek [...]” [wz: 291]. „Koszula, która dniem i nocą styka się bezpośrednio z ciałem, symbolizuje intymne «ja» [...]” [Toussaint-Samat 2002: 323] - zauważa autorka Historii stroju, a nie od dziś wiadomo, że „bliższa koszula ciału”. W tę pozornie nienaruszalną przestrzeń „pomiędzy” wkraczają ulotki - obowiązek spiskowca, który tak rozumianą ojczyznę ma, dosłownie, na sercu. Później jeszcze przez jakiś czas po emigracji dawny buntownik niepotrzebnie wykorzystuje buty jako element zbędnych już konspiracyjnych praktyk:

Jeszcze parę miesięcy i, przyklękając na ulicy, aby zawiązać [sznurowadło,

uświadamiasz sobie, że robisz to, aby zawiązać sznurowadło, nie po to, aby rutynowo zerknąć przez ramię,

czy ktoś za tobą nie idzie.

[Druga natura, wz: 302]

Także współspiskowcy powracać będą we wspomnieniach jeszcze w Widokówce z tego świata pojawia się obraz trudnej do oswojenia wizyty ${ }^{13}$ „Krawczyka Olgierda”, mężczyzny też rozprowadzającego „bibułę”, ale tak innego od poety-dysydenta. Wizerunek gościa jest wyrazisty m.in. poprzez odtworzenie elementów garderoby: „staromodne trzaśnięcie obcasów”, „w wiecznej kurtce z zielonej dermy”, „dopiero potem zaczynał / pakować numery gazetek we flanelowe zanadrze”, „Chrzęst kurtki” [ Grudzień 1976,

„W utworze nie ma mowy o «inwazyjności» tej wizyty, ale nagromadzenie głoski «r» podkreśla dysonans, czy też może raczej: niepokój czy napięcie, jakie wizyta ta wnosi (pojawiają się już w imieniu i nazwisku gościa, chrzęście kurtki, czerni smaru)" [Kopeć 2016: 133]. 
WZ: 363]. Jak zauważa Pawelec [1995: 154], frazy: „bo w takim szyku, z tym szykiem / zwykł się przedstawiać naszym spłoszonym żonom" [wz: 363] nie odsyłają tylko do składni, bo „szyk” występuje ,jako porządek, układ wyrazów w zdaniu” i ,jako elegancja, wytwornośc”.

\section{5. (Na)stroje poety}

Metafora tekstylna sprawdza się także w sformułowaniu „programu" poetyckiego. Tak dzieje się już w pełnych rozterek Wzruszeniach $\mathrm{z}$ tomu Korekta twarzy. Tytułowe wzruszenia $\mathrm{z}$ jednej strony mają okryć "grzbiet / cierpkiego wciąż-to-samo” i „wystające / żebra, co drą aksamit”, są „złożone na krzyż z płaszczących się części, / ubogo przewidzianych"; z drugiej strony mogą też zwieść na manowce „wybranych”, których „zostawiono z płaszczem na ramionach" [wz: 9] - wbrew zachętom do jego zrzucenia, znanym z Czarnej wiosny Antoniego Słonimskiego. W innym wczesnym tekście, wierszu Szept, słowa mają być „jak aktor / w obcisłym stroju, gładki” [wz: 18]. „Garderobiane” dodatki, chociaż ze zwierzęcego rejestru, narzucają poetycki rygor, konieczność podporządkowania się pismu: „[...] wbij się w te ciasne obroże z kolcami” [Pismo, wz: 45], „w te kolczaste obroże musisz wcisnąć szyję" [Kotysanka, wz: 104]. W Myśleniu dzwonem pojawia się spójna z takim pisaniem, radykalna koncepcja etyczna, która może przywodzić na myśl „suchy poemat moralisty” i frazę „tak - tak / nie - nie" z Kołatki Zbigniewa Herberta [2011: 102-103]. Obok metafor związanych z pracą dzwonu pojawiają się „opończe rozmysłu”, „obroże wątpliwości” oraz postulat symbolizowanej nagością jednoznaczności - zarówno zgody, jak i odmowy:

Uprościć dzwonem opończe rozmysłu, obroże wątpliwości, rozwiązać dwojako nagość odmowy, nagość zgody, strącać ich osobność ze szczytu dzwonić - aż ziemia, aż skała niech się rozstąpi w bujnych kołach, coraz szerszych.

[wZ: 22] 
Już bez młodzieńczego radykalizmu, ale wciąż po stronie formy - tak można by skomentować późniejszy o mniej więcej dwie dekady przykład wykorzystania elementów stroju do zaprezentowania poetyckich założeń. W Drobnomieszczańskich cnotach w przeciwstawieniu własnej postawy wizji ,artysty J." wyliczono szereg antynomii, w tym garderobianą (tu dodatkowo dwuznaczną, skoro „pod muchą” potocznie znaczy „po pijanemu”): „jak to, ja pod krawatem, kiedy on pod muchą, / ja skrępowany, zapięty, gdy on ostatnią z koszul / rozrywa jak krwawiącą pierś! Filisterski brak serca!"14 [wz: 354]. O tym wierszu Barańczak [1993: 69] mówił w wywiadzie:

Trzeba znać te ciemne otchłanie, które są w nas, i trzeba umieć się do nich przed sobą przyznać, ale nie znaczy to, że musimy innych zmuszać do pochylania się nad nimi, a już zwłaszcza że musimy innych w nie wciągaćt ${ }^{15}$.

Styl to człowiek - można by przypomnieć. Także styl ubierania się.

W innym tekście wyraz sceptycznego podejścia do amerykańskiej domowej wyprzedaży, na której kupić można m.in. „jaskrawe bluzki”, w utworze Yard sale przechodzi w spór z Bogiem, który zarzuca poecie "przebranie ${ }^{{ }{ }_{16} \text { : }}$

Tak wygląda to w wersji Jacka Bierezina, który uznał się za drugiego z bohaterów tekstu i napisał w odpowiedzi Wielomiesięczne kryzysy: ,jak to, on pod krawatem, a ja pod muchą, / on skrępowany, zapięty, a ja ostatnią z koszul / rozrywam jak krwawiącą pierś! Czysta dostojewszczyzna!" [OE: 45].

15 Podobnie czytają ten wiersz choćby Tomasz Mizerkiewicz [2001: 222]: „Okazuje się, że kondycję zapiętego na ostatni guzik sztukatora słowa określa w równym stopniu jego zewnętrzna ułożoność, jak i szereg skrywanych onieśmieleń, zawstydzeń, niepokojów, czyli kłębiących się w świadomości małych pesymizmów, którym nieustannie trzeba stawiać czoła” i Lech Giemza [2008: 429]: „Tym samym - tu kolejny typowo Barańczakowy paradoks - pod powierzchnią żartu kryje się poważne rozpoznanie jednej z ułomności naszych czasów: cierpienie stało się towarem na rynku idei. Tymczasem przysługuje mu wewnętrzny rygor i powściągliwość, by nie sprowadzić go do maskarady czy gry pozorów”.

16 „Oburzony deskrypcyjną śmiałością podmiotu Bóg lustruje literacką wyprzedaż poetyckich chwytów [...]. Wypowiedź ta ma na celu demaskację kreacji poety. Wykorzystane w wierszu zabiegi instrumentacyjnie (mimiczne weny; strój, mina) sprawiają, iż za pomocą brzmienia poeta nabiera rysów cyrkowego artysty - 
„A w Tobie skąd ten sarkazm. Te twoje żałosne zakurzone odkrycia, wizje w kiepskim guście, $[\ldots]$

to przebieranie sensu w sztuczne włókna mowy. Może po to te szmaty, te mimiczne weny,

bym przyjąl, że strój, mina, cały ten umowny kształt nie może być tobą, że masz coś lepszego w zanadrzu, jakiś wiecznie trzymany w kieszeni dowód, iż jesteś godny mnie [...].

[wZ: 352$]$

Sens przebrany „w sztuczne włókna mowy”, „te szmaty” i „strój” metafora tekstylna ujawnia tu silny metapoetycki, krytyczny potencjal, chociaż twórca nie pozostaje Bogu dłużny w zarzutach. Jednak, jak zaświadczają Tenorzy, zewnętrzną śmieszność można wielkim artystom wybaczyć:

Tenorzy, czemu was kocham? Przecież wszyscy jesteście [tłustawi.

Pomiędzy białą muszką a w ciup rozwartymi ustami podbródki: podwójne, podwójnie pocące się. Rozhuśtani

na podwyższonych obcasach $[\ldots]$.

[wZ: 431]

Warto na marginesie przypomnieć, że pewna nobliwość stroju, która w Drobnomieszczańskich cnotach stanowi składnik poetyckiego programu opartego na emocjonalnej powściągliwości, pojawia się też w wypowiedziach o samym Barańczaku. Zbigniew Kopeć [2016: 131] przypomina, że Czesław Miłosz i Barańczak byli „poetami w togach”; Piotr Śliwiński [2007] tytułuje swój tekst Melancholik pod krawatem; wywiad Michała Okoń-

mima występującego na scenie życia. Jego rolą staje się nieustanna, metapoetycka gra pozorów, gdy tymczasem nic poza tą grą nie istnieje” [Dembińska-Pawelec 1999: 130]. 
skiego i Adama Szostkiewicza z Barańczakiem to Poeta $w$ krawacie [Okoński, Szostkiewcz 1994], a Tadeusz Nyczek [2008: 7] wspomina:

To, że ów subtelny uniwersytecki naukowiec w garniturze zaangażuje się w młodzieżową kontrkulturę, że zacznie pisać namiętne wiersze wyrafinowane w formie i antysocjalistyczne w treści, było równie zdumiewające, ale wtedy jakoś nikt się nie dziwił.

Trudno byłoby oczekiwać przy tak zarysowanej poetyckiej strategii wielu osobistych, wyraźnie prywatnych odzieżowych opowieści. Owszem, N.N. znajduje „fotografię dziecka w białych podkolanówkach (pamiątka / pierwszej komunii) [...]” [N.N. porzadkuje papiery osobiste, wz: 149]; w Korekcie twarzy pojawia się porównanie: „Kiedyś ja sama w ciebie wejdę, niczym ręka / w rękawiczkę [...]" [Pusty ${ }^{17}$, wz: 16], a w erotyku Wrzesień 1967 - obraz kochanków zdzierających z siebie ubrania. W pamięci tkwi też sierpień, który „[...] przejdzie, już przeszedł do historii mojego ciała / jak epoka mokrych koszul, pod którymi skóra nie wiedziała, / czy skrapla się na niej pot, czy rekordowa wilgotność powietrza” [Sierpień 1988, wz: 369]. Zatarło się wprawdzie w pamięci, czy w dniu wydarzeń z wiersza Hemofilia na pewno chodziło o konieczność znalezienia w sklepie akurat płaszcza, za to na emigracji wciąż żywe jest młodzieńcze wspomnienie związane z butami: „Stać obiema stopami na twardym gruncie tej chwili, / gdy kostka jezdni podbiega zakosem, uderza piekąco w podeszwy / i, wytracając pęd, łomocząc trampkami w licealnej torbie” [Nie używać słowa „wygnanie”, wz: 303]. Emigrancki „rytuał przejścia”, wylot z kraju, też kojarzy się z obrazem buta, skoro „[...] dywan już się wyrywał / spod zabryzganej jeszcze miejscowym błotem podeszwy” [Ziemia usuwata się spod nóg, wz: 304]. To jednak tylko pojedyncze frazy, jakiegoś tajemniczego dopełnienia, którego wszystkie płaszczyzny „przeplatają się, unieważniając wzajemnie" [Kaniewska 2014: 24]. 
oswajające lub utrwalające trudne bądź po prostu przełomowe doświadczenia, zakorzeniające je w materialnym (materiałowym) konkrecie $^{18}$.

Świat w poezji Barańczaka pozwala się - czasem, na chwilę obnażyć właśnie poprzez tekstylne metafory. „Najcięższe krawiectwo", czyli wizja skończoności, świadomość bycia zaledwie „ciałem w jesionce” [wZ: 222], rodzi jednak, też zaprezentowane w postaci katalogu strojów, strategie oporu. Mechanizmy obronne jako zimowe szaliki (1.11.79: Elegia pierwsza, przedzimowa, 20.3.80: Elegia czwarta, przedwiosenna), elegancki strój na cotygodniowy spacer (Od Knasta) - metody to może iluzoryczne, ale pozwalające przynajmniej zachować fason wobec nieuniknionego. W utworach wyraźnie zakorzenionych w konkretnym ustroju tekstylne metafory pozwalają na pokazanie fałszu systemu (Przysłowiowa bawetna), grozy totalitaryzmów i sytuacji jednostki wobec nich (W zasadzie niemożliwe, N.N. rozmyśla o dalszych perspektywach). $\mathrm{Z}$ kolei przyjęcie roli opozycjonisty wprowadza dalsze rygory „modowe”, choćby ojczyznę „od ciała do koszuli, na grubość / pliku świeżych ulotek" [wz: 291] czy odkrywanie podobieństw między wolnością i zniewoleniem, gdy siedzi się na komisariacie „z brulionem własnych wierszy / ukrytym [...] w nogawce zimowej bielizny" [wz: 252]. W aspekcie metapoetyckim garderoba ma natomiast potencjał jako wyraz zachowania zdystansowanej formy (Drobnomieszczańskie cnoty) oraz jako metafora w sporach o poetę - sceptycznego wobec sztuczności obserwowanych wydarzeń, chociaż przecież i jego cechuje „przebieranie sensu w sztuczne włókna mowy" [Yard sale, wZ: 352]. fizyczności, namacalności. Punktem wyjścia jest zawsze naoczne doświadczenie. Nawet w pierwszym tomie, gdy powoływane były do życia obrazy nadrealne, bardziej znaczące niż pokazujące, odwoływały się one do wyobrażenia tego, co dostępne zmysłom. [...] W późniejszej twórczości ta naoczność będzie wręcz znakiem rozpoznawczym wierszy Barańczaka” [Biedrzycki 2006]. 
Metafora tekstylna - by przypomnieć słowa autorki Przymiarek do istnienia zapisane w kontekście poezji kobiet - to środek ujawniający „zaangażowanie tej poezji w doczesność i wieczność” [Grądziel-Wójcik 2016: 8]. Tak jest też w twórczości Barańczaka. Wybrane do niniejszego artykułu przykłady pokazują, jak - czasem za pomocą wyrazistej metafory, a czasem po prostu przez przywołanie ubraniowego konkretu w funkcji znaku czasów albo elementu zapadającej w pamięć sytuacji - człowiek próbuje się adekwatnie ubrać, czy może wręcz uzbroić przeciw „przebranemu, nieprzebranemu” światu.

\section{Bibliografia}

Barańczak Stanisław (1990), E.E., przybysz z innego świata, w: tegoż,

Tablica z Macondo. Osiemnaście prób wyttumaczenia, po co i dlaczego się pisze, „Aneks”, Londyn [Wielka Brytania], s. 191-199.

Barańczak Stanisław (1993), „Poezja musi być wieczna czujnościa”.

Rozmowa z Piotrem Wierzchosławskim, w: tegoż, Zaufać nieufności.

Osiem rozmów o sensie poezji 1990-1992, red. Krzysztof Biedrzycki, M, Kraków, s. 59-79.

Barańczak Stanisław (2007), Wiersze zebrane, as, Kraków. (Skrót: wz) Biedrzycki Krzysztof (1995), Świat poezji Stanisława Barańczaka,

Universitas, Kraków.

Biedrzycki Krzysztof (2006), Przywracanie porządku [online], [dostęp:

27 grudnia 2018], http://stronypoezji.pl/monografie/przywracanieporzadku/.

Bogalecki Piotr (2016), „Rozwiecznione w horyzont”. Wieki średnie Stanisława Barańczaka [online], „Przestrzenie Teorii”, nr 26, s. 31-51, [dostęp: 2 stycznia 2020], https://doi.org/10.14746/pt.2016.26.2.

Bokszańska Grażyna (2004), Ubiór w teatrze życia społecznego,

Wydawnictwo Politechniki Łódzkiej, Łódź.

Bolecki Włodzimierz (1985), Język jako świat przedstawiony. O wierszach Stanisława Barańczaka, „Pamiętnik Literacki”, z. 2, s. 149-174.

Dembińska-Pawelec Joanna (1999), Światy możliwe w poezji Stanistawa Barańczaka, Wydawnictwo Uniwersytetu Śląskiego, Katowice.

Giemza Lech (2008), Ironiczny autoportret Stanisława Barańczaka, „Napis”, seria XIV, s. 421-431.

Grądziel-Wójcik Joanna (2016), Przymiarki do istnienia. Wątki i tematy poezji kobiet XX $i$ XXI wieku, Wydawnictwo Naukowe UAM, Poznań. 
Herbert Zbigniew (2011), Wiersze zebrane, a5, Kraków.

Kandziora Jerzy (2007), Ocalony w gmachu wiersza. O poezji Stanisława Barańczaka, Fundacja Akademia Humanistyczna, Instytut Badań Literackich PAN, Warszawa.

Kaniewska Bogumiła (2014), Barańczak i rodzaj żeński, w: Poeta i duch wolności. Szkice o twórczości Stanisława Barańczaka, red. Piotr Śliwiński, Wydawnictwo wbpicak, Poznań, s. 23-34.

Kopeć Zbigniew (2016), Świat jako zadanie dla inteligenta. O dwóch wierszach Stanistawa Barańczaka („Spójrzmy prawdzie w oczy”, „Grudzień 1976”) [online], „Przestrzenie Teorii”, nr 26, s. 131-138, [dostęp: 2 stycznia 2020], https://doi.org/10.14746/pt.2016.26.7.

Mizerkiewicz Tomasz (2001), Potępieńcze swary? O sporze Bierezina $z$ Barańczakiem, „Polonistyka”, nr 4, s. 220-224.

Nyczek Tadeusz, wybrał, ułożył i skomentował (1995), Określona epoka. Nowa Fala 1968-1993. Wiersze i komentarze, Oficyna Literacka, Kraków. (Skrót: OE)

Nyczek Tadeusz (2008), Precyzja i chaos, „Polonistyka”, nr 3, s. 6-8.

Okoński Michał, Szostkiewcz Adam (1994), Poeta $w$ krawacie [rozmowa ze Stanisławem Barańczakiem], „Tygodnik Powszechny”, nr 51-52, s. 12-13.

Opacka-Walasek Danuta (2016), „.. . ta próba jest grana tak, że się na raz dzieja wszystkie sceny". Teatralizacje Stanisława Barańczaka, w: Literatura polska wświecie, t. 6: Barańczak. Postscriptum, red. Romuald Cudak, Karolina Pospiszil, Gnome, Katowice, s. 27-42.

Pawelec Dariusz (1992), Poezja Stanisława Barańczaka. Reguty i konteksty, „Śląsk”, Katowice.

Pawelec Dariusz (1995), Czytając Barańczaka, Gnome, Katowice.

Pawelec Dariusz (1998), Dojść do siebie. Wiersze Stanisława Barańczaka, w: tegoż, Debiuty i powroty. Czytanie w czas przełomu, Agencja Artystyczna „PARA”, Katowice, s. 61-67.

Poprawa Adam (2003), Kwestia formy, w: tegoż, Formy i afirmacje, Universitas, Kraków, s. 77-80.

Poprawa Adam (2014), Międzyludzkie Barańczaka, w: Poeta i duch wolności. Szkice o twórczości Stanisława Barańczaka, red. Piotr Śliwiński, Wydawnictwo wbpicAK, Poznań, s. 9-21.

Śliwiński Piotr (2007), Melancholik pod krawatem, w: „Obchodzę urodziny z daleka...” Szkice o Stanisławie Barańczaku, red. Joanna Dembińska-Pawelec, Dariusz Pawelec, Wydawnictwo Uniwersytetu Śląskiego, Katowice, s. 75-85.

Toussaint-Samat Maguelonne (2002), Historia stroju, przeł. Krystyna Szerzyńska-Maćkowiak, W.A.B., Warszawa. 
Kamila Czaja

'The world disguised, bottomless'. Textile metaphor in Stanisław Barańczak's poetry

The article discusses the issue of textile metaphor and its function in Stanisław Barańczak's poetry - a topic that used to be discussed mainly in relation to women's poetry. In his poems, Barańczak uses elements of garments as a means to capture abstract and often dangerous aspects of existence and as a symbol of a system or a characteristic of citizens living in a specific time. Textile metaphor allows him to expose the falsehood of the system and the threat of totalitarianism, while also constituting part of a dissident's everyday equipment. References to parts of garments are a way to present the poetic programme and the ambiguous role of an artist. In a 'disguised' and dangerous world of poetry marked by a secret difficult to 'uncover', one is, in a way, sentenced to dress against the requirements imposed on them by reality.

Keywords: Stanisław Barańczak; contemporary poetry; textile metaphor; garments in poetry.

Kamila Czaja - doktor nauk humanistycznych w dyscyplinie literaturoznawstwo, redaktor naczelna dwutygodnika kulturalnego „artPAPIER”, autorka książki (Nie)przygotowani. Metafora szkoły w polskiej poezji wspótczesnej (2018), kilkunastu artykułów w monografiach naukowych oraz kilkudziesięciu esejów i recenzji publikowanych w ,artPAPIERZE”, „FA-arcie” i „Twórczości”; zajmuje się przede wszystkim polską poezją współczesną i piosenką poetycką. Adres e-mail: kamila.czaja@us.edu.pl. 